\title{
PENELITIAN
}

\section{GULA POVIDINE-IODINE 1\%: ALTERNATIF PENGOBATAN LUKA TEKAN}

\author{
Amelia Kurniati *
}

\begin{abstract}
Abstrak
Luka tekan (luka akibat penekanan yang terus menerus) adalah masalah yang umum terjadi pada kelompok klien tertentu seperti klien usia lanjut, klien kritis, dan klien yang menderita kelumpuhan. Luka tekan ini menimbulkan banyak masalah: tingginya biaya yang dikeluarkan untuk mengobati luka, menurunnya kualitas hidup klien, lamanya dirawat di rumah sakit, dan meningkatnya angka kematian klien. Penelitian dilakukan untuk membandingkan efektivitas pemakaian balutan modern (hydrocolloid) dan gula povidine-iodine $1 \%$ di 4 rumah sakit di Jakarta selama 2 bulan dengan menggunakan desain non-equivalent control group pre dan posttest. Didapat total sampel sebanyak 25 klien, dibagi secara random ke dalam 2 kelompok; kelompok hydrocolloid dan kelompok gula povidine-iodine $1 \%$. Setiap sampel dilakukan pretest, kemudian dirawat selama 3 minggu, dan setiap minggu perawatan dilakukan posttest oleh peneliti. Hasil yang didapat adalah tidak ada perbedaan yang bermakna untuk pengecilan area luka tekan walaupun ketika membandingkan kecepatan penghancuran jaringan mati dan kecepatan pertumbuhan granulasi, terlihat bahwa kedua keadaan ini lebih cepat terjadi di kelompok gula povidine-iodinee 1\%-. Untuk biaya perawatan lebih tinggi di kelompok hydrocolloid, sedangkan untuk lamanya waktu perawatan luka lebih cepat.
\end{abstract}

Kata kunci: Luka tekan, gula povidine-iodine, hydrocolloid, penyembuhan luka, lama perawatan, biaya perawatan.

\section{Abstract}

Pressure ulcers (ulcers which caused by body pressure) are common problems in some sub-specific patients, such as, elderly patients, critical-ill and para paraplegia patients. Pressure ulcers induces problems: the costs involved, patients' quality of life and mortality rate. Research purposed to compare the efectivity hydrocolloid dressing and sugar Povidine-iodine (1\%) dressing. Research has been conducted within the 4 selected hospitals in 2 months period of time using non equivalen control group; pre and post test. Total sample was 25 patients, which divided onto 2 groups: hydrocolloid group and sugar povidineiodinee group. Pre-test was also done to obtain initial data to be used for further treatments with hydrocolloid dressing and sugar Povidine-iodine (1\%) dressing. Each patient was treating for 3 weeks, and in each week was conducted a post-test. Results from processing the data obtained, indicating that there was no significant difference on wound size reduction. The cost involved was higher in the hydrocolloid group while the nursing time consumption was lower.

Key words: Pressure ulcer, sugar-povidine-iodinee, hydrocolloid, wound healing, nursing time consumption, cost.

\section{LATAR BELAKANG}

Ide penelitian ini muncul karena selama di klinik peneliti melihat perbedaan perawatan luka yang diberikan kepada klien yang mempunyai luka tekan (pressure ulcer). Perbedaan terjadi pada cara perawatan dan penggunaan berbagai produk perawatan luka; dari produk balutan luka modern; hydrocolloid dan alginate, perawatan luka konvensional; perawatan luka dengan kasa basah, atau pun yang campuran seperti gula povidine-iodine.

Keragaman jenis perawatan luka ini tidak didukung dengan dokumentasi yang menjelaskan tingkat keberhasilan masing-masing balutan dalam proses penyembuhan luka tekan. Karena ketiadaan rujukan, perawatan luka tekan selama ini dilakukan hanya berdasarkan protokol yang berlaku di rumah sakit. Sementara sebagai perawat yang bertanggung jawab untuk mencegah dan menyembuhkan luka tekan sangat perlu untuk melakukan perawatan luka yang didasari oleh fakta. Ditambah lagi, di tengah krisis multi dimensional sekarang ini, dibutuhkan cara yang relatif murah, mudah dalam peracikannya, dan terbukti efektifitasnya untuk meningkatkan proses penyembuhan luka tekan. Berdasarkan hal ini peneliti membandingkan efektifitas perawatan luka tekan dengan membandingkan balutan modern, pada penelitian ini dipakai hydrocolloid, dengan gula Povidine-iodine $1 \%$. 
Masalah penelitian yang timbul adalah:

1) Apakah ada perbedaan yang bermakna dalam pengecilan luka (dalam persen) antara pemakaian balutan hydrocolloid dengan gula povidine-iodine $1 \%$ ?

2) Apakah ada perbedaan yang bermakna dalam biaya yang digunakan pada perawatan luka tekan antara pemakaian balutan hydrocolloid dengan gula povidine-iodine $1 \%$ ?

3) Apakah ada perbedaan yang bermakna dalam waktu perawatan luka tekan antara pemakaian balutan hydrocolloid dengan gula povidine-iodine $1 \%$ ?

\section{TINJAUAN PUSTAKA}

Luka tekan didefinisikan oleh National Pressure Ulcer Panel Concencus (NPUAP, 1994) sebagai luka yang disebabkan oleh tekanan yang terus menerus yang menimbulkan kerusakan pada jaringan yang tertekan. Luka ini biasanya terjadi pada jaringan di atas tulang yang terus menerus tertekan dan mempunyai 4 tingkatan; tingkat I jika terjadi kemerahan di daerah tertekan; tingkat II jika ada lapisan yang hilang meliputi epidermis, dermis atau keduanya; tingkat III jika kehilangan seluruh jaringan subkutan; dan tingkat IV jika jaringan yang hilang atau ada nekrosis sampai kejaringan otot, tulang, atau organ lainnya.

NPUAP (1994) menyatakan bahwa luka tekan bisa terjadi pada setiap klien di rumah sakit. Khususnya pada klien yang dirawat di ruangan kegawatan (ICU/ICCU), klien yang menderita patah tulang paha atau kelumpuhan, dan klien lanjut usia karena kurangnya mobilisasi mereka. Di Amerika Serikat sekitar 9\% klien dari seluruh klien yang dirawat menderita luka tekan (NPUAP, 1994), 54 66\% klien dari seluruh klien yang berusia 70 - 80 tahun (Meehan, 1994: Olson et al, 1996), 60\% klien dari klien yang lumpuh (Olson, 1994), dan 11,1\% klien dari 148 klien di ruang keperawatan kegawatan (Meehan, 1994). Data dari United Kingdom menunjukkan adanya kemiripan; 5 - 9\% klien menderita luka tekan dari seluruh klien yang dirawat, 70\% klien dari klien yang berusia lebih dari 70 tahun(Young \& DobranZki, 1992), dan 9,8\% klien yang dirawat di ruang kegawatan (Anthony, 1996).

Luka tekan memberikan dampak yang kurang baik pada pelayanan keperawatan; 1). Dana yang sangat besar untuk pengobatan (NPUAP, 1994; Bryant, 1992; Young
\& Dobranzki, 1992), 2). Penurunan kualitas hidup, penderitaan, timbulnya gangguan bentuk dan lebih lama dirawat di rumah sakit (Whittle et al, 1996), 3). Peningkatan sampai 5 - 6 kali lipat angka kematian pada klien usia lanjut (Young \& Dobranzki, 1992; Gunnewicht, 1995). Padahal jika luka tekan diobati dengan tepat, maka kerugian-kerugian di atas dapat dikurangi (Bryant, 1992; NPUAP, 1994; Potter \& Perry, 1997).

Di bawah ini adalah tinjauan kepustakaan yang membandingkan kedua jenis balutan yang dipakai dalam penelitian ini.

\section{Balutan hydrocolloid}

Balutan hydrocolloid adalah balutan modern yang terbuat dari serat yang bersifat kenyal dan dilapisi oleh lapisan luar yang fleksibel dan tahan air (Fowler, Cuzzell\& Papen, 1991) sehingga dapat mempertahankan kelembaban dasar luka (moist wound surface) yang tepat untuk proses pertumbuhan jaringan. Permukaan yang tidak permiabel ini menciptakan penahan bagi kumankuman dan lingkungan luka yang rendah pHnya yang menekan pertumbuhan bakteri, serta menimbulkan lingkungan yang rendah kadar oksigennya yang dapat menginduksi perkembangan jaringan granulasi (Bryant, 1992; Field \& kerstein, 1994; Kim et. El, 1997; Thomas, et. Al, 1997).

Balutan hydrocolloid dapat dipakai dan tetap berfungsi optimal $4-7$ hari, sehingga menurunkan kerusakan pada jaringan granulasi yang baru tumbuh yang mudah sekali rusak karena seringnya diganti, serta balutan ini bebas dari partikel-partikel yang dapat menempel di luka dan menyebabkan lamanya proses penyembuhan seperti balutan konvensional (misalnya balutan dari kasa) (Field \& Kerstein, 1996; Cho \& Lo, 1998). Balutan hydrocolloid relatif mahal, walaupun banyak penelitian menemukan karena mudah penggunaannya balutan ini menurunkan lamanya waktu yang diperlukan untuk merawat luka (Colwell, 1993; Kim et al, 1996; Bale et al, 1997; Thomas et al. 1997).

\section{Gula Povidine-iodine 1\%}

Gula sudah digunakan dalam pengobatan luka sejak 2000 BC (Greenwood, 1993), umumnya di Colombia dan Argentina dan kurang umum di United Kingdom, Jepang danUganda(Forrest, 1982; Shimamoto, et al. 1986; Greenwood, 1993; Dawson, 1995). Beberapa laporan 
keberhasilan pengobatangulaterhadap luka tekan atau luka terinfeksi menjelaskan bahwa terdapat penurunan area luka, nyeri, nanah, jaringanmati, sertamenstimulasitumbuhnyajaringan granulasi(Base, 1982; Forest, 1982; Archer, 1987; Mayauchi et al, 1991; Greenwood, 1993; Bazzigapuli, 1991 in Anthony, 1996; Thopham, 1996). Forest (1982), secara khusus menyatakan bahwa proses penyembuhan luka dalam yang sangat baik ini yang timbul di daerah tropis adalah akibat humiditas yang tinggi yang dapat membuat dasar lukatetap lembab.

Gula povidine-iodine dapat membunuh banyak kuman; Staphilococcus aureus (tidak termasuk Methicilin-resistan Staphilococcus aureus/MRSA), E coli, $\mathrm{S}$ thpymurium, $\mathrm{P}$ aeruginosa dan $\mathrm{P}$ mirabilitus dalam 10 menit pemakaian (Shiraishi, Oka \& Nagakawa, 1997). Mereka memprediksi hal ini timbul karena gula povidine-iodine pada luka menciptakan lingkungan ber-pH 4,0 - 4,6 dan memiliki osmolalitas tinggi yang dapat menghambat pertumbuhan bakteri (Thomas, 1990; Shiraishi, Oka \& Nagakawa, 1997). Tingginya osmolalitas larutan gula dilaporkan juga dapat menurunkan udema jaringan sekitar luka dan menghancurkan jaringan yang mati sehingga luka bersih dan siap untuk pertumbuhan jaringan (Base, 1982; Forrest, 1982; Acher, 1987; Greenwood, 1993; Topham, 1996; Rund, 1996).

Tabel 1

Perbedaan antara hydrocolloid dengan gula Povidine-iodine $1 \%$.

\begin{tabular}{lll}
\hline \multicolumn{1}{c}{ Perbedaan } & hydrocolioid & $\begin{array}{c}\text { gula Providine- } \\
\text { iodinee 1\% }\end{array}$ \\
\hline Harga & Rp. 50.000/ helai & Rp. 150/15 mg \\
\hline Buatan & Australia & Indonesia \\
\hline Cara pemakaian & $\begin{array}{l}\text { Langsung bisa } \\
\text { dipakai }\end{array}$ & Diracik peneliti \\
\hline Lama pemakaian & $\begin{array}{l}\text { 4-7 hari jika } \\
\text { tidak bermasalah }\end{array}$ & $\begin{array}{l}\text { 1 hari sekali jika } \\
\text { tidak bermasalah }\end{array}$ \\
\hline
\end{tabular}

\section{BAHAN DAN CARA KERJA}

Penelitian menggunakan desain Kuasi-eksperimen, khususnya non-equivalent control group dengan pre dan post test. Pemilihan sampel menggunakan purposive sampling, dilakukan di empat rumah sakit di Jakarta selama 2 bulan (25 Januari sampai 23 Maret 1999).
Sampel dipilihdengan kriteria inklusif: 1). Klien berusia 20 tahun atau lebih dengan lukatekan tingkat II, III, atau IV (sesuai NPUAP) dan bersedia menandatangani informed consent (atau orang yang mewakilinya); 2). Luka tidak terinfeksi (ditandai dengan ketiadaan kemerahan, nanah, panas, dan bengkak), dan tidak memilikieksudat yang sangat banyak halini karena hydrocolloid tidak dapat dipakai pada luka terinfeksi, 3). Klien tidak memilikiriwayat alergidengan jenis balutan yang digunakan,4). Klientidakmemiliki penyakit kanker karena kanker dapat memperpanjang proses penyembuhan luka (Bryant, 1992; Morison, 1992; Potter \& Perry, 1997).

Pada penelitian, klien yang memiliki luka tekan diidentifikasi setiap ronde pagi oleh rekan-rekan perawat ruangan di keempat rumah sakit yang dipakai penelitian, namun pengkajian dilakukan oleh peneliti. Klien kemudian diberikan penjelasan tentang penelitian, tujuan, kegunaan dan untung ruginya mengikuti penelitian. Setelah klien atau orang yang bertanggung jawab akan klien menandatangani lembar persetujuan maka peneliti melakukan pengkajian lebih jauh lagi.

Pengambilan data awal (pre-tes) dilakukan terhadap setiap luka tekan yang meliputi; 1) data demografi klien, 2) luas permukaan luka yang diukur dengan menggunakan transparency tracing film untuk menggambar bentuk luka, kemudian dihitung dengan ukuran $1 \times 1 \mathrm{~cm}^{2}$, dan 3) warna jaringan luka dan atau jaringan mati.

Post-test dilakukan setiap kelipatan hari ke-7 saat balutan diganti dan diteruskan sampai luka sembuh atau maksimum sampai 3 minggu pengobatan luka karena adanya keterbatasan waktu penelitian. Data yang dikumpulkan meliputi; 1) luas permukaan luka, 2) warna jaringan luka dan atau jaringan mati, 3) biaya yang dikeluarkan dengan menjumlahkan total alat disposable yang dipakai dikalikan dalam rupiah, 4) waktu perawatan luka (dalam menit).

Beberapa variabel intra dan ekstra tidak dapat dikontrol pada penelitian ini, seperti; 1) kualitas pelayanan keperawatan lainnya yang diberikan kepada klien, 2) jenis-jenis tempat tidur yang ada, 3) dan variasi kondisi klien seperti; status nutrisi, mobilitas, beratnya penyakit, serta kadar albumin klien. Karenanya hasil penelitian ini hanya menggambarkan efek perawatan luka pada klien yang memenuhi kriteria yang ditentukan. 


\section{HASIL PENELITIAN}

Sejumlah 32 klien yang masuk dalam penelitian, namun 6 diantaranya keluar karena; 3 klien meninggal selama penelitian dan 3 lainnya digugurkan karena perawat ruangan menggunakan balutan jenis lain saat dilakukan penelitian. Hanya 26 klien yang diikutkan penelitian secara penuh, yang ditempatkan secara random ke dalam kelompok I (13 klien) untuk hydrocolloid dan kelompok II untuk gula povidine-iodine $1 \%$ (13 klien).

Data awal yang terkumpul kemudian dicek dari nilai ekstrim dengan SPSS versi 8.0. Terdapat 1 data ekstrim dari perempuan berusia 48 tahun, di kelompok gula povidine-iodine $1 \%$. Ditemukan bahwa luas permukaan luka tekan klien adalah 450 $\mathrm{cm} 2$ dan ada di tingkat IV. Karena nilai ekstrim (outliers) sangat mempengarui standar deviasi dan nilai rata-rata (Munro, p 48, 1997), maka data tersebut dihilangkan oleh peneliti.

\section{Data Demografi}

Klien terbanyak dirawat di rumah sakit A (10 klien) yang merupakan rumah sakit terbesar dan rujukan Indonesia bagian barat dan yang terkecil (3 klien) dirawat di rumah sakit C. Terdapat penyebaran yang merata antara klien laki-laki dan klien perempuan di kedua kelompok balutan, dengan rentangan umur berkisar 20-72 tahun.

Hasil tes homogenitas data di antara kedua kelompok klien yaitu; status kesehatan umum, kemampuan mobilisasi (pergerakan), status eliminasi (kemampuan mengontrol buang air besar dan kecil), dan penyakit kencing manis menunjukkan tidak ada perbedaan proporsi yang bermakna di antara kedua kelompok yang diteliti:

1) status umum kesehatannya; penderita luka tekan terbanyak memiliki status kesehatan yang buruk, diikuti status sedang dan baik (chisquare $0.36, \mathrm{p}=0,83$ )

2) rentang imobilisasi klien; terbanyak klien immobilisasi (8 klien) dan terkecil untuk klien yang tetap mobil (4 klien) (chi-square $4.77 \mathrm{p}=0,189$ )

3) status eliminasi; 9 klien dikelompok I dan 10 dikelompok II, tidak dapat mengontrol buang air besar dan kecil
4) kencing manis; 7 klien menderita kencing manis di kelompok I dan 11 klien dikelompok II (chi-square $2,5 \mathrm{p}=0,114)$.

\section{Karakteristik Luka Tekan}

Karakteristik luka tekan yang masuk sebagai sampel meliputi; tingkatan luka, lokasi, keadaan jaringan luka, dan keadaan jaringan granulasi. Umumnya tingkatan luka tekan di kelompok I ada di tingkat II (7 luka), sedangkan kelompok II luka terbanyak ada di tingkat IV (7 luka). Rata-rata luka berada di daerah sakrum (tulang ekor) sebanyak 8 luka untuk kelompok I dan 9 luka di kelompok II, dengan kondisi luka tertutup oleh jaringan ikat yang berwarna kehitaman, dan kondisi jaringan granulasi sedang sampai kurang baik.Hasil

\section{Pengecilan Area Luka}

Hasil non parametik test (Mann Whitney U test) menunjukkan bahwa tidak ada perbedaan yang bermakna untuk pengecilan area luka antara kelompok I dan kelompok II $(\mathrm{p}=0,012)$ selama 3 minggu perawatan. Ketika data dianalisis untuk within-subject data (data dalam I kelompok penelitian) dengan menggunakan Friedman test menunjukkan bahwa selama 3 minggu perawatan di kelompok I tidak terjadi perbedaan yang bermakna untuk pengecilan area luka $(\mathrm{p}=0,033)$, sedang di kelompok II terjadi pengecilan area luka yang cukup bermakna $(\mathrm{p}=0,000)$.

Peneliti mengasumsikan bahwa tidak tampaknya perbedaan yang bermakna untuk pengecilan area luka dapat terjadi karena rata-rata proses penyembuhan luka tekan tingkat III dan IV terjadi lebih dari 2 bulan (Van Rijswijk L. \& Polansky M., 1994) sedangkan penelitian ini hanya dilakukan selama 3 minggu, sehingga perbedaan tidak dapat dideteksi. Peneliti menganalisis data lebih jauh untuk membandingkan pengurangan jaringan nekrotik dan peningkatan jaringan granulasi antara dua kelompok penelitian, didapat hasil;

\section{1) Pengurangan jaringan mati (nekrotik)}

Hasil menunjukkan adanya perbedaan yang bermakna untuk pengurangan jaringan mati di antara dua kelompok $(\mathrm{p}=0,003)$. Pengurangan jaringan mati di kelompok II terjadi terutama pada minggu I dan II, sehingga pada akhir perawatan (minggu III) pada kelompok II jaringan mati sudah tidak ada. 


\section{2) Peningkatan Jaringan Granulasi}

Percepatan penghancuran jaringan mati lebih tinggi di kelompok II, sehingga proses granulasi lebih cepat terjadi. Hal ini ditunjukkan dengan penurunan tingkat luka tekan (dari IV ke III ke II). Dengan analisa deskriptif di kelompok II terdapat lebih banyak luka yang turun tingkat keparahannya (granulasi berjalan lebih baik) di akhir perawatan (66,7\%), dibanding kelompok I hanya 38,5\%.

Kesimpulan yang didapat berdasarkan kecepatan penghancuran jaringan mati dan kecepatan tumbuhnya jaringan granulasi adalah bila penelitian dilakukan lebih lama, maka akan didapatkan perbedaan yang bermakna untuk pengecilan area luka tekan di antara dua kelompok tersebut.

\section{Biaya yang dibutuhkan}

Total biaya yang dibutuhkan dihitung dari total biaya alat-alat yang dikeluarkan. Terdapat beda yang sangat besar $(\mathrm{p}=0,000)$. Bila memakai hydrocolloid biayanya Rp. 247.000 per klien (Rp. 19.000 setiap kali perawatan) sedang gula povidine-iodine 1\% Rp. 78.000 per klien (Rp. 6.500 setiap kali perawatan).

\section{Waktu Perawatan yang Dibutuhkan}

Waktu perawatan dihitung dari perawat menyiapkan alat-alat sampai luka dibalut dan alatalat dirapihkan. Rata-rata waktu yang dibutuhkan di kelompok I adalah 100 menit, sedang dikelompok II 342 menit $(\mathrm{p}=0,000)$. Lalu lamanya waktu perawatan dikali dengan gaji yang didapatkan tiap menit (Rp 600.000/ bulan: 40 jam kerja/bulan: 60 menit) Rp. 250,00, sehingga didapat total biaya seperti tertera di bawah ini (tabel 3). Hasil akhir menunjukkan bahwa; walaupun biaya perawatan (labour cost) diperhitungkan ternyata balutan hydrocolloid tetap lebih mahal dibanding gula povidine-iodine $1 \%$.

Tabel 3

Total biaya yang dibutuhkan

\begin{tabular}{lrrr}
\hline $\begin{array}{c}\text { Group of } \\
\text { treatments }\end{array}$ & $\begin{array}{c}\text { Material cost } \\
\text { (Rp.) }\end{array}$ & $\begin{array}{c}\text { Labour cost } \\
\text { (Rp.) }\end{array}$ & $\begin{array}{c}\text { Total cost } \\
\text { (Rp.) }\end{array}$ \\
\hline Hydrocolloid & 19.000 & 1.750 & 20.750 \\
Gula povidine-iodine & 6.500 & 4.875 & 11.375 \\
\hline
\end{tabular}

\section{KESIMPULAN}

Peneliti menyimpulkan bahwa gula povidine-iodine $1 \%$ menunjukkan hasil yang lebih baik untuk penyembuhan luka tekan dan juga jauh lebih murah dibandingkan hydrocolloid. Keterbatasan penelitian ini antara lain; sampel yang cukup kecil sehingga kekuatan analisa (power of analysis) tidak cukup kuat hanya menggambarkan kelompok sampel yang diambil. Perlu dilakukan penelitian yang melibatkan sampel lebih banyak dan lebih terbuka lagi dalam pemilihan sampel sehingga akan didapat hasil yang lebih kuat dan lebih mewakili populasi umum klien yang dirawat $(\mathrm{HH})$.

Amelia Kurniati, S.Kp., MN: Staf pengajar bagian keperawatan medikal bedah FIK-UI

\section{KEPUSTAKAAN}

Acher, H. dkk. (1987). Toxicity of topical sugar. Lancet. 1:854S, 1485-1486.

Anthony, D. (1996). The treatment of pressure ulcer: Acentury of misinformation in the textbook. Journal of Advanced Nursing. Aug 24(2):309-16.

Bale, S. dkk. (1997). A comparison of two dressings in pressure sore management. Journal of Wound care, Nov.6(10):463-466.

Bennet, G. dan Moody, M. (1995). Wound care for health proffesionals. London: Chapman \& Hall.

Bryant, R. (1992). Acute and chronic wound care: Nursing management. St. Louis: Mosby Year Book.

Flanagan, M. (1997). Wound management. New York: Churchill Livingstone.

Forrest, R.D. (1982). Sugar in the wound. Lancet. Jan (I):8276-861.

Kim, Y.C. dkk. (1996). Efficacy of Hydrocolloid occlusive dressing technique in decubitus ulcer treatment: a comparative study. Yonsei Medical Journal._371(3\}: 181 - 185.

Miyauchi, H. dkk. (1990). Comparative study of treatment of decubitus using three ointments: Reflap ointment, povidine iodine sugar and combination of both ingredients. Skin Research. 32(4):547-563.

National Pressure Ulcer Advhsory Panel (NPUAP) 1994. Clinical practical guidelines number 15: Pressure ulcer treatment . USA: Department of Health and Hurnan Service Publications

Shimamoto, Y. dkk (1986). Topical application ot sugar and povidine iodine in the management of decubitus ulcer in aged patients. Hiroshima Journal of Medical Sciences. Jun.35(2): 167-168.

Thomas, S. (1990). Wound management and dressing. London: The Pharmaceutical Press. 